12. Kutzbach, J. E. \& Guetter, P. J. The influence of changing orbital patterns and surface boundary conditions on climate simulations for the past 18,000 years. J. Atmos. Sci. 43, 1726-1759 (1986)

13. Hall, N. M. J., Valdes, P. J. \& Dong, B. The maintenance of the last great ice sheets: a UGAMP GCM study. J. Clim. 9, 1004-1009 (1996).

14. Barnosky, C. W. A record of late-Quaternary vegetation from the southwestern Columbia Basin, Washington. Quat. Res. 23, 109-122 (1985).

15. Sarna-Wojcicki, A. J. in Late Quaternary Environments of the United States Vol. 2 (ed. Wright, H. E. Jr) 52-77 (Univ. Minnesota, Minneapolis, 1983).

16. Berger, G. W. \& Busacca, A. J. Thermoluminescence dating of Late Pleistocene loess and tephra from eastern Washington and southern Oregon and implications for the eruptive history of Mount St. Helens. J. Geophys. Res. 100, 22361-22374 (1995).

17. Grimm, E. C. in Vegetation History (eds Huntley, B. \& Webb, T.) 53-76 (Kluwer, Dordrecht, 1988) 18. Martinson, D. G. et al. Age dating and the orbital theory of the ice ages: development of a high resolution 0 to 300,000-year chronostratigraphy. Quat. Res. 27, 1-29 (1987).

19. Mack, R. N. \& Bryant, V. M. Jr Modern pollen spectra from the Columbia Basin, Washington. Northwest Sci. 48, 183-194 (1974).

20. Franklin, J. F. \& Dyrness, C. T. Natural Vegetation of Oregon and Washington (Oregon State Univ., Corvallis, 1988).

21. Bond, G. et al. Correlations between climate records from North Atlantic sediments and Greenland ice. Nature 365, 143-147 (1993).

22. Imbrie, J. et al. in Milankovitch and Climate (eds Berger, A., Imbrie, J., Hays, J., Kukla, G. \& Saltzman, B.) 269-305 (Reidel, Dordrecht, 1984)

23. Berger, A. \& Loutre, M. F. Insolation values for the last 10 million years. Quat. Sci. Rev. 10, 297-317 (1991).

24. Greenland Ice-core Project (GRIP) Members. Climate instability during the last interglacial period recorded in the GRIP ice core. Nature 364, 203-207 (1993).

25. Thouveny, N. et al. Climate variations in Europe over the past $140 \mathrm{kyr}$ deduced from rock magnetism. Nature 371, 503-506 (1994).

26. Morley, J. J., Pisias, N. G. \& Leinen, M. Late Pleistocene time series of atmospheric and oceanic variables recorded in sediments from the subarctic Pacific. Paleoceanography 2, 49-62 (1987).

27. Stuiver, M. \& Reimer, P. J. Extended ${ }^{14} \mathrm{C}$ data base and revised CALIB $3.0{ }^{14} \mathrm{C}$ age calibration program. Radiocarbon 35, 215-230 (1993).

28. Bard, E., Hamelin, B., Fairbanks, R. G. \& Zindler, A. Calibration of the ${ }^{14} \mathrm{C}$ timescale over the past 30,000 years using mass spectrometric U-Th ages from Barbados corals. Nature 345, 405-410 (1990).

29. Mazaud, A., Laj, C., Bard, E., Arnold, M. \& Tric, A. E. Geomagnetic field control of ${ }^{14} \mathrm{C}$ production over the last $80 \mathrm{kyr}$ : implications for the radiocarbon time-scale. Geophys. Res. Lett. 18, 1885-1888 (1991) 30. Cleveland, W. S. Visualizing Data (Hobard, Summit, 1993).

Acknowledgements. We thank A. Sarna-Wojcicki for tephra identifications, R. J. Nickmann for help with the pollen analysis, and J. Guiot and R. E. Gresswell for reviews. The work was supported by the NSF and the Westinghouse-Hanford Paleoclimate Program.

Correspondence and requests for materials should be addressed to C.W. (e-mail: whitlock@oregon uoregon.edu).

\title{
Endemic African mammals shake the phylogenetic tree
}

\section{Mark S. Springer*, Gregory C. Cleven*, Ole Madsen†, Wilfried W. de Jong $\dagger \neq$, Victor G. Waddell $\varsigma$, Heather M. Amrine ${ }^{\star} \&$ Michael J. Stanhope $\$$}

* Department of Biology, University of California, Riverside, California 92521, USA

$\dagger$ Department of Biochemistry, University of Nijmegen, PO Box 9101, 6500 HB Nijmegen, The Netherlands

$\ddagger$ Institute for Systematics and Population Biology, University of Amsterdam, PO Box 94766, 1090GT Amsterdam, The Netherlands

$\$$ Biology and Biochemistry, Queen's University, 97 Lisburn Road, Belfast BT9 07BL, UK

The order Insectivora, including living taxa (lipotyphlans) and archaic fossil forms, is central to the question of higher-level relationships among placental mammals ${ }^{1}$. Beginning with Huxley $^{2}$, it has been argued that insectivores retain many primitive features and are closer to the ancestral stock of mammals than are other living groups ${ }^{3}$. Nevertheless, cladistic analysis suggests that living insectivores, at least, are united by derived anatomical features ${ }^{4}$. Here we analyse DNA sequences from three mitochondrial genes and two nuclear genes to examine relationships of insectivores to other mammals. The representative insectivores are not monophyletic in any of our analyses. Rather, golden moles are included in a clade that contains hyraxes, manatees, elephants, elephant shrews and aardvarks. Members of this group are of presumed African origin ${ }^{5,6}$. This implies that there was an extensive African radiation from a single common ancestor that gave rise to ecologically divergent adaptive types. $12 \mathrm{~S}$ ribosomal RNA transversions suggest that the base of this radiation occurred during Africa's window of isolation in the Cretaceous period before land connections were developed with Europe in the early Cenozoic era.

Relationships among orders of placental mammals have proved difficult to resolve ${ }^{1}$. To extend the available mitochondrial $(\mathrm{mt})$ sequences, a 2.6-kilobase ( $\mathrm{kb}$ ) segment containing the $12 \mathrm{~S}$ rRNA, valine transfer RNA, and 16S rRNA genes was sequenced for nine taxa to generate a data set that is representative of 12 of the 18 placental orders and all three insectivore suborders ${ }^{4}$. Phylogenetic analyses provide strong support for well-established mammalian clades such as carnivores, hominoids, and Cetacea plus Artiodactyla (Fig. 1a). In agreement with other molecular studies ${ }^{7-10}$ that included an assortment of taxa, most interordinal associations are not resolved at bootstrap values $>75 \%$. However, the mtDNA data do provide strong support for the association of the two paenungulates (hyrax, manatee) together, and of these with elephant shrews, aardvarks and golden moles (Fig. 1a and Table 1). The association of hyraxes with proboscideans and sirenians was suggested by Cope ${ }^{11}$. A competing hypothesis is an association of hyraxes with perissodactyls ${ }^{12}$. Our results agree with earlier protein $^{13,14}$ and DNA studies ${ }^{7-10}$ supporting Cope's paenungulate hypothesis. In addition to bootstrap support, T-PTP ${ }^{15}$ and KishinoHasegawa ${ }^{16}$ tests also support paenungulate monophyly (Table 2). Anatomical data provide some evidence that aardvarks and/or elephant shrews may be related to paenungulates ${ }^{17,18}$ but suggest other hypotheses as well: for example, six osteological features are putative synapomorphies uniting elephant shrews with lagomorphs and rodents ${ }^{19}$. All the available sequence data, including amino-acid sequences $^{13,14}$, DNA sequences for three nuclear genes ${ }^{8-10}$, and the present mitochondrial genes, support an association of aardvarks and elephant shrews with paenungulates. What is most unexpected is that golden moles, a family of insectivores, are also part of this clade. $12 \mathrm{~S}$ rRNA sequences earlier suggested an association of golden moles with paenungulates, but did not provide convincing bootstrap support for this hypothesis ${ }^{7}$. Our expanded data set demonstrates that insectivores are not monophyletic (Table 2)

\begin{tabular}{|c|c|c|}
\hline & \multicolumn{2}{|c|}{ Clade } \\
\hline & Paenungulata & $\begin{array}{c}\text { Paenungulata }+ \text { aardvark } \\
\text { + elephant shrew } \\
\text { +golden mole }\end{array}$ \\
\hline \multicolumn{3}{|l|}{ Mitochondrial DNA } \\
\hline Parsimony & 99 & 95 \\
\hline Transversion parsimony & 64 & 90 \\
\hline \multicolumn{3}{|l|}{ Minimum evolution } \\
\hline Tamura-Nei I & 100 & 92 \\
\hline Tamura-Nei II & 100 & 78 \\
\hline Logdet & 99 & 90 \\
\hline Maximum likelihood & 100 & 100 \\
\hline \multicolumn{3}{|l|}{ VWF } \\
\hline \multicolumn{3}{|l|}{ Parsimony } \\
\hline All positions & 49 & 99 \\
\hline 1st and 2nd positions & 24 & 65 \\
\hline 3rd positions & 51 & 93 \\
\hline Transversion parsimony & 30 & 95 \\
\hline \multicolumn{3}{|l|}{ Minimum evolution } \\
\hline Tamura-Nei I & 37 & 99 \\
\hline Tamura-Nei II & 30 & 99 \\
\hline Logdet & 43 & 97 \\
\hline Maximum likelihood & 78 & 100 \\
\hline \multicolumn{3}{|l|}{$\mathrm{A} 2 \mathrm{AB}$} \\
\hline \multicolumn{3}{|l|}{ Parsimony } \\
\hline All sites & 71 & 88 \\
\hline 1st and 2nd positions & 49 & 81 \\
\hline 3rd positions & 31 & 67 \\
\hline Transversion parsimony & 71 & 54 \\
\hline \multicolumn{3}{|l|}{ Minimum evolution } \\
\hline Tamura-Nei I & 83 & 84 \\
\hline Tamura-Nei II & 28 & 25 \\
\hline Logdet & 79 & 78 \\
\hline Maximum likelihood & 81 & 89 \\
\hline
\end{tabular}

Only two of the three paenungulate orders were represented among the mitochondrial and A2AB sequences. Tamura- $\mathrm{Ne}^{27} \mid$ and II distances were calculated by using an equal-rates assumption and a gamma-distribution of rates, respectively. 
a
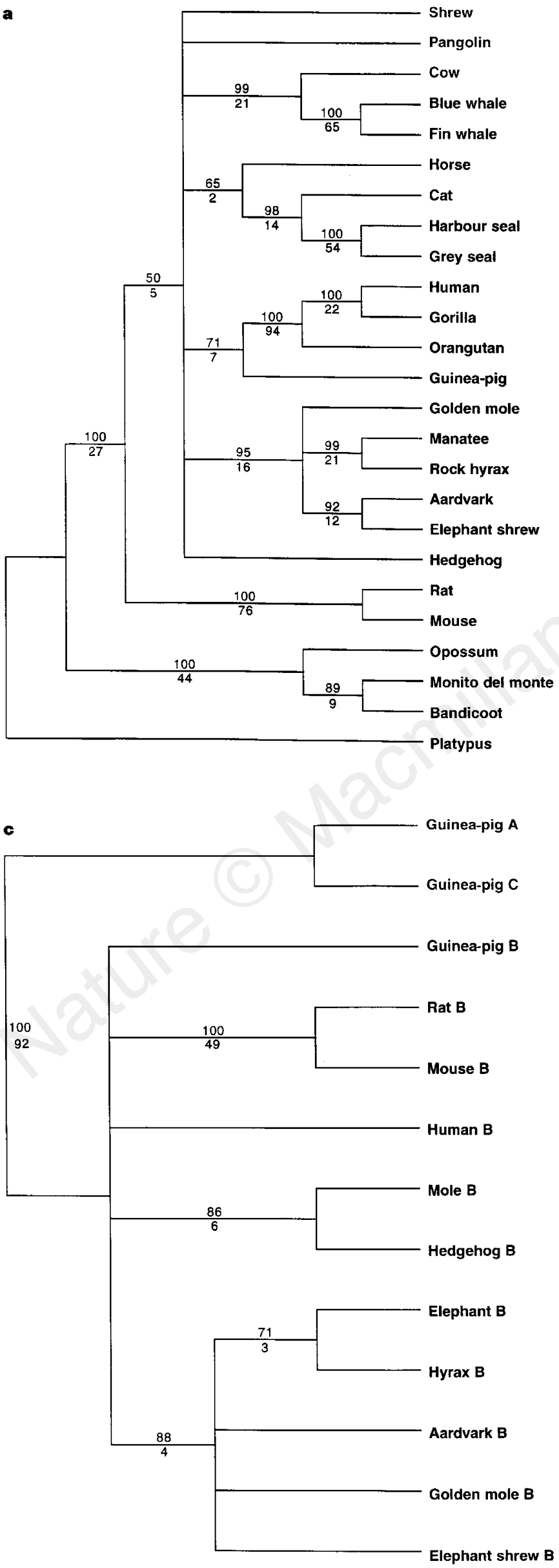

b

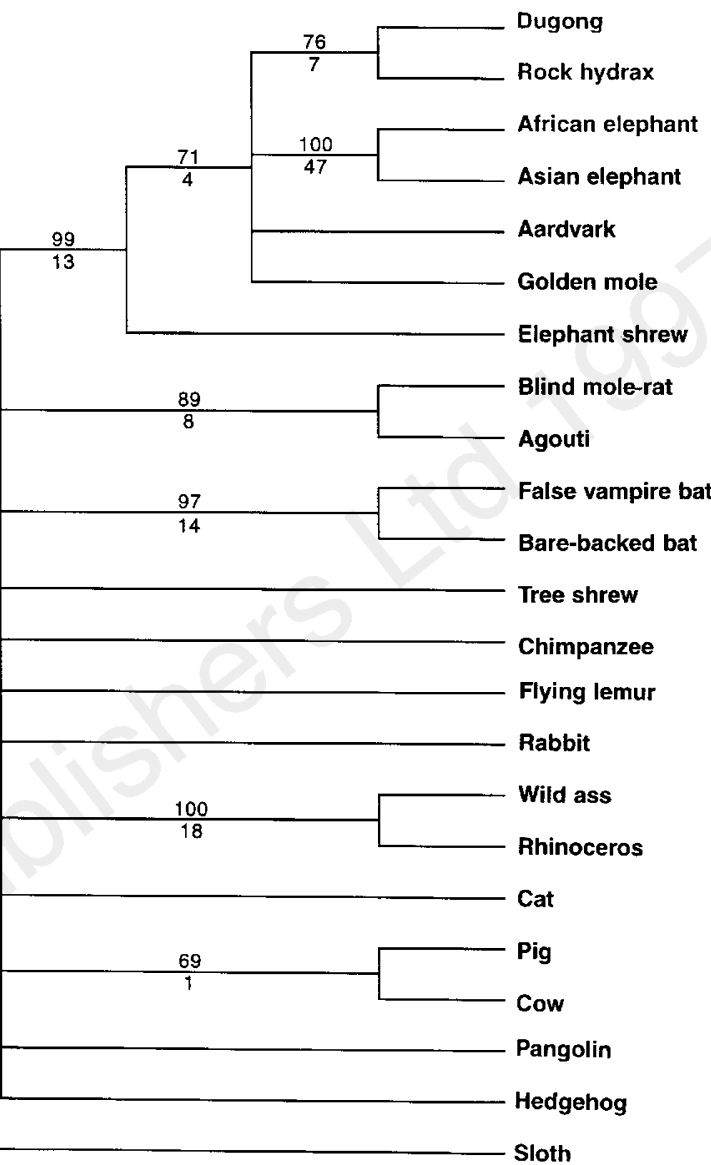

Figure 1 Majority-rule parsimony bootstrap trees based on mitochondrial (a), VWF (b), and A2AB (c) sequences. Bootstrap values and decay indices, respectively, are above and below branches. The minimum-length tree $(3,836$ steps; consistency index, 0.430) for the mitochondrial data is 4, 7, 43 and 66 steps shorter than trees that constrain shrew + hedgehog, rodent monophyly, insectivore monophyly, and hyrax + horse, respectively. Insectivore monophyly and a hyrax-perissodactyl association require 29 and 64 additional steps, respectively, in comparison to five minimum-length VWF trees (2,401 steps; consistency index, 0.511). Insectivore monophyly requires 26 additional steps in comparison to the shortest A2AB tree (1,469 steps; consistency index, 0.730). 


\begin{tabular}{|c|c|c|c|c|}
\hline \multirow[t]{2}{*}{ Constraint } & \multicolumn{4}{|c|}{ Mitochondrial DNA } \\
\hline & T-PTP & \multicolumn{2}{|c|}{$\mathrm{KH}-\mathrm{P}$} & $\mathrm{KH}-\mathrm{L}$ \\
\hline $\begin{array}{l}\text { Perissodactyls + hyracoids } \\
\text { Insectivore monophyly }\end{array}$ & $\begin{array}{l}0.01 \\
0.05\end{array}$ & \multicolumn{2}{|c|}{$0.0011-0.0022$} & $<0.0001$ \\
\hline \multicolumn{5}{|c|}{$\begin{array}{l}\text { In each case, trees with constraints were compared against either minimum length (T-PTP, } \\
\text { Kishino-Hasegawa test with parsimony; KH-L, Kishino-Hasegawa test with maximum likeli }\end{array}$} \\
\hline \multicolumn{5}{|c|}{ Table 3 Divergence times (Myr) based on 12S rRNA transversions } \\
\hline Divergence event & $N$ & Mean & $\begin{array}{l}\text { Standard } \\
\text { deviation }\end{array}$ & $\begin{array}{c}\text { Standard } \\
\text { error }\end{array}$ \\
\hline Among Paenungulates & 3 & 54.8 & 4.2 & 2.4 \\
\hline Paenungulates to golden mole & 3 & 67.1 & 8.7 & 5.0 \\
\hline Paenungulates to aardvark & 3 & 74.0 & 12.0 & 6.9 \\
\hline Paenungulates to elephant shrew & 3 & 79.9 & 9.9 & 5.7 \\
\hline African clade to other 13 orders & 78 & 91.1 & 15.5 & 1.6 \\
\hline
\end{tabular}

and that golden moles, elephant shrews, aardvarks and paenungulates are part of the same clade.

To corroborate these findings, we obtained sequences from exon 28 of the von Willebrand factor (vWF) gene for golden mole, hedgehog and pangolin. Adding these to the existing vWF data set $^{9}$, we found high bootstrap support for the inclusion of golden moles with paenungulates, elephant shrews and aardvarks (Fig. 1b and Table 1). Sequences from the $\alpha-2 \mathrm{~B}$ adrenergic receptor gene $(A 2 A B)$ also support the association of golden moles with paenungulates, elephant shrews and aardvarks (Fig. 1c and Table 1). Parsimony and maximum-likelihood trees supporting the paenungulate-golden mole-aardvark-elephant shrew clade are significantly better than the best trees that constrain insectivore monophyly (Table 2).

This expanded clade, which includes five placental orders plus golden moles, has not been previously hypothesized on the basis of morphological or molecular data. Elephants, sirenians, hyraxes, golden moles, aardvarks and elephant shrews show a variety of ecological and morphological specializations and it is not surprising that morphology has not elucidated their common ancestry, now evident from DNA sequences. It is notable that all six of these groups are of probably African origin or, in the case of the aquatic sirenians, from along the margins of the former Tethys Sea ${ }^{5,6,13}$. In two cases (golden moles and elephant shrews), geographic distribution has been restricted to Africa for the complete temporal range of these taxa ${ }^{5}$. Thus geographic evidence adds to the molecular data in support of this 'African origin' clade. The radiation of the African clade parallels endemic radiations of other vertebrate taxa on Southern Hemisphere continents during the breakup of Gondwanaland; for example, marsupials and passerine birds in Australia ${ }^{20}$, and marsupials, edentates and notoungulates in South America ${ }^{5}$.

Paenungulate orders diverged from each other 51 to 59 million years (Myr) ago, as deduced from 12S rRNA transversions (Table 3). Deeper in the African clade, average divergence times between paenungulates and other lineages range from 67 to $80 \mathrm{Myr}$. The mean divergence time between taxa in the African clade and the other 13 orders of placental mammals is $\sim 91$ Myr. These divergence times support the hypothesis that many eutherian orders arose before the extinction of dinosaurs at the end of the Cretaceous ${ }^{21}$ and imply that conventional views on the origins of the African mammal fauna $^{5}$ are incorrect. Africa's window of isolation extended from the Late Cretaceous, when Africa became separated from South America, to the early Cenozoic, when tenuous connections developed between northern Africa and Europe. The window of isolation extended from at least $80 \mathrm{Myr}$ (ref. 20), if not earlier, until the early Cenozoic. The traditional view is that condylarths, prosimian primates and creodont carnivores reached Africa from the north after the docking of Africa with Europe $e^{5}$. From the condylarth stock, groups such as proboscideans and sirenians ostensibly originated in
Africa. Other elements of the African mammal fauna, including perissodactyls, artiodactyls, insectivores and living carnivore families, presumably arrived in the Neogene with the establishment of the Arabian Peninsula. Evidence for an extensive African clade, including taxa with divergence times as old as $80 \mathrm{Myr}$, is inconsistent with this view. The ancestor of the African clade probably resided in Africa before the window of isolation and did not arrive from the north in the early Cenozoic. The role of geographic isolation and continental break-up in the early diversification of placental mammals is potentially more important than previously recognized.

\section{Methods}

Amplification and sequencing. 12S rRNA and tRNA genes were amplified and sequenced as described ${ }^{22} .16 \mathrm{~S}$ rRNA genes were amplified using primers for valine-tRNA (for example, $5^{\prime}$-tacaccyaraagatttca- $3^{\prime}$ ) and leucine-tRNA (for example, $5^{\prime}$-agaggrtttgaacctctg-3') and sequenced. Accession numbers for the new mitochondrial sequences (Echymipera kalubu (bandicoot); Dromiciops gliroides (monito del monte); Sorex palustris (shrew); Manis sp. (pangolin); Amblysomus hottentotus (golden mole); Procavia capensis (hyrax); Trichechus manatus (manatee); Orcyteropus afer (aardvark); Elephantulus rufescens (elephant shrew)) are U97335-U97343. 12S rRNA sequences for several of these taxa have been deposited in GenBank (M95108 (golden mole), U61073 (monito del monte), U61079 (pangolin), U61083 (manatee), U61084 (hyrax)). Accession numbers for additional mitochondrial sequences are as follows: cow (J01394); blue whale (X72204); fin whale (X61145); horse (X79547); cat (U20753) harbour seal (X63726); grey seal (X72004); human (J01415); gorilla (D38114); orang-utan (D38115); guinea-pig (L35585); hedgehog (X88898); rat (X14848); mouse (J01420); opossum (Z29573); platypus (U33498; X83427). Exon 28 of the vWF gene was amplified and sequenced as described ${ }^{9}$. Accession numbers for Manis sp., Erinaceus europaeus (hedgehog), and Amblysomus hottentotus vWF sequences are U97534-U97536. Additional vWF sequences are from ref. 9. Part of the single-copy, intronless $A 2 A B$ gene was amplified using the primers A2ABFOR ( $5^{\prime}$-asccctactcngtgcaggcnacng- $3^{\prime}$ ) and A2ABREV $\left(5^{\prime}\right.$-ctgttgcagtagccdatccaraaraaraaytg- $\left.3^{\prime}\right)$. PCR products were cloned into a $\mathrm{T} /$ A cloning vector (Promega) and both strands were sequenced for at least two clones using the Thermo Sequenase fluorescent-labelled primer cycle sequencing kit (Amersham). Accession numbers for the new $A 2 A B$ sequences (Elephas maximus (elephant); Orycteropus afer (aardvark); Macroscelides proboscideus (elephant shrew); Amblysomus hottentotus (golden mole); Procavia capensis (hyrax); Erinaceus europaeus (hedgehog); Talpa europaea (mole)) are Y12520Y12526. Additional $\alpha-2$ adrenergic sequences are M34041 (human); M32061 (rat); (L00974) (mouse), and U25722-U25724 (guinea-pig).

Sequence alignment and phylogenetic analysis. Sequences were aligned using CLUSTAL W (ref. 23). rRNA alignments were modified in view of secondary structure ${ }^{24,25}$. Ambiguous regions were omitted from subsequent analyses $^{26}$; this resulted in 2,152, 1,261 and 1,132 nucleotide positions, respectively, for the $\mathrm{mt}, \mathrm{vWF}$ and $\mathrm{A} 2 \mathrm{AB}$ genes. The $\mathrm{mt}, \mathrm{vWF}$ and $\mathrm{A} 2 \mathrm{AB}$ data sets contain 810, 497 and 393 informative sites, respectively. Phylogenetic analyses (parsimony, minimum evolution with Tamura-Nei ${ }^{27}$ and $\operatorname{Logdet}^{28}$ distances, maximum likelihood under the HKY85 (ref. 29) model) were conducted with PAUP 4.0d52-54, written by D. L. Swofford. The mitochondrial tree was rooted using platypus and marsupial sequences. The vWF tree was rooted with the sloth ${ }^{7}$; alternatively, rooting with either hedgehog or rodents supports the 'African' clade and contradicts insectivore monophyly. For the $\mathrm{A} 2 \mathrm{AB}$ tree, sequences with the suffix $\mathrm{B}$ are from the $\mathrm{A} 2 \mathrm{AB}$ subfamily. GuineaPigA and GuineaPigC sequences are from other subfamilies in the $\alpha-2$ adrenergic receptor family and were used as outgroups. Bootstrap analyses used full heuristic searches with 500 replications for parsimony and minimum 
evolution and 100 replications for maximum likelihood. Shape parameters for the gamma distribution were estimated from minimum length trees ${ }^{26}$ and were 0.32 (mtDNA), 0.59 (vWF) and 0.52 (A2AB).

Divergence times. $12 \mathrm{~S}$ rRNA transversions accumulated linearly as far back as the eutherian-metatherian split ${ }^{24}$. Nine independent cladogenic events were selected based on 12S rRNA sequence availability and paleostratigraphic data $^{10,24,30}$ (for example, Rattus to Mus (14 Myr); Sus to Tayassu (45 Myr); ruminants to Cetacea (60 Myr); Erinaceus to Metatheria (130 Myr)). Relative rates were calculated in reference to xenarthrans. Tamura-Nei transversion distances (transversions only) were adjusted for relative rate differences ${ }^{30}$ against the xenarthran standard. Rate-adjusted estimates of sequence divergence were regressed against paleostratigraphic divergence estimates for each of the nine calibration points (origin forced through zero; $r^{2}=0.97$; $P=0.0000002$ ). The resulting equation (divergence time (in Myr) $=$ sequence divergence/0.00063) was used to estimate interordinal divergence times after making similar adjustments for relative rates. Additional details will be presented elsewhere (M.S., manuscript in preparation).

Received 23 December 1996; accepted 18 April 1997.

1. Novacek, M. J. Mammalian phylogeny: shaking the tree. Nature 356, 121-125 (1992).

2. Huxley, T. H. On the application of the laws of evolution to the arrangement of the Vertebrata, and more particularly to the Mammalia. Proc. R. Soc. Lond. 43, 649-662 (1880).

3. Matthew, W. D. The Carnivora and Insectivora of the Bridger Basin, Middle Eocene. Mem. Am. Mus. Nat. Hist. 9, 291-567 (1909).

4. MacPhee, R. D. E. \& Novacek, M. J. in Mammal Phylogeny Vol. 2, Placentals (eds Szalay, F. S., Novacek M. J. \& McKenna, M. C.) 13-31 (Springer, New York, 1993),

Carroll, R. L. Vertebrate Paleontology and Evolution (Freeman, New York, 1988).

6. Gheerbrant, E., Sudre, J. \& Cappetta, H. A Palaeocene proboscidean from Morocco. Nature 383, 68 70 (1996).

7. Lavergne, A., Douzery, E., Stichler, T., Catzeflis, F. M. \& Springer, M. S. Interordinal mammalian relationships: evidence for paenungulate monophyly is provided by complete mitochondrial $12 \mathrm{~S}$ rRNA sequences. Mol. Phyl. Evol. 6, 245-258 (1996).

8. Madsen, O., Deen, P. M. T., Pesole, G., Saccone, C. \& de Jong, W. W. Molecular evolution of mammalian aquaporin-2: further evidence that elephant shrew and aardvark join the paenungulate clade. Mol. Biol. Evol. 14, 363-371 (1997).

9. Porter, C. A., Goodman, M. \& Stanhope, M. J. Evidence on mammalian phylogeny from sequences of exon 28 of the von Willebrand factor gene. Mol. Phys. Evol. 5, 89-101 (1996).

10. Stanhope, M. J. et al. Mammalian evolution and the interphotoreceptor retinoid binding protein (IRBP) gene: convincing evidence for several superordinal clades. J. Mol. Evol. 43, 83-92 (1996)

11. Cope, E. D. The condylarthra. Am. Nat. 18, 790-805, 892-906 (1884).

12. Fischer, M. S. \& Tassy, P. in Mammal Phylogeny Vol. 2, Placentals (eds Szalay, F. S., Novacek, M. J. \& McKenna, M. C.) 217-234 (Springer, New York, 1993).

13. de Jong, W. W., Zweers, A. \& Goodman, M. Relationship of aardvark to elephants, hyraxes and sea cows from $\alpha$-crystallin sequences. Nature 292, 538-540 (1981)

14. de Jong, W. W., Leunissen, J. A. M. \& Wistow, G. J. in Mammal Phylogeny Vol. 2, Placentals (eds Szalay, F. S., Novacek, M. J. \& McKenna, M. C.) 5-12 (Springer, New York, 1993).

15. Faith, D. P. Cladistic permutation tests for monophyly and nonmonophyly. Syst. Zool. 40, 366-375 (1991).

16. Kishino, H. \& Hasegawa, M. Evaluation of the maximum likelihood estimate of the evolutionary tree topologies from DNA sequence data, and the branching order in Hominoidea. J. Mol. Evol. 29, 170 179 (1989).

17. Glover, T. D. Aspects of sperm production in some east African mammals. J. Reprod. Fertil. 35, 45-53 (1973).

18. Hartenberger, J. L. Hypothese paleontologique sur l'origine des Macroscelidea (Mammalia). C.R. Acad. Sci. 302, 247-249 (1986).

19. Novacek, M. in Macromolecular Sequences in Systematic and Evolutionary Biology (ed. Goodman, M.) 3-41 (Plenum, New York, 1982).

20. Sibley, C. G. \& Ahlquist, J. E. Reconstructing bird phylogeny by comparing DNAs. Sci. Am. 254, 82-92 (1986).

21. Hedges, S. B., Parker, P. H., Sibley, C. G. \& Kumar, S. Continental breakup and the ordinal diversification of birds and mammals. Nature 381, 226-229 (1996).

22. Springer, M. S., Hollar, L. J. \& Burk, A. Compensatory substitutions and the evolution of the mitochondrial 12S rRNA gene in mammals. Mol. Biol. Evol. 12, 1138-1150 (1995).

23. Thompson, J. D., Higgins, G. D. \& Gibson, T. J. CLUSTAL W: improving the sensitivity of progressive multiple sequence alignment through sequence weighting, position-specific gap penalties and weight matrix choice. Nucleic Acids Res. 22, 4673-4680 (1994).

24. Springer, M. S. \& Douzery, D. Secondary structure and patterns of evolution among mammalian mitochondrial 12 S rRNA molecules. J. Mol. Evol. 43, 357-373 (1996).

25. De Rijk, P., Van de Peer, Y., Chapelle, S. \& De Wachter, R. Nucleic Acids Res. 22, 3495-3501 (1994).

26. Swofford, D. L., Olsen, G. J., Waddell, P. J. \& Hillis, D. M. in Molecular Systematics (eds Hillis, D. M. Moritz, C. \& Mable, B. K.) 407-514 (Sinauer, Sunderland, MA, 1996).

27. Tamura, K. \& Nei, M. Estimation of the number of nucleotide substitutions in the control region of mitochondrial DNA in humans and chimpanzees. Mol. Biol. Evol. 10, 512-526 (1993).

28. Lockhart, P. J., Steel, M. A., Hendy, M. D. \& Penny, D. Recovering evolutionary trees under a more realistic model of sequence evolution. Mol. Biol. Evol. 11, 605-612 (1994).

29. Hasegawa, M., Kishino, H. \& Yano, T. Dating of the human-ape splitting by a molecular clock of mitochondrial DNA. J. Mol. Evol. 21, 160-174 (1985).

30. Arnason, U., Gullberg, A., Janke, A. \& Xu, X. Pattern and timing of evolutionary divergences among hominoids based on analyses of complete mtDNAs. J. Mol. Evol. 43, 650-661 (1996).

Acknowledgements. This work was supported by the Alfred P. Sloan Foundation, the European Commission, the NSF, the Nuffield Foundation and the Royal Society. We thank D. Willemsen for technical assistance, D. Swofford for permission to use PAUP 4.0d52-54, and F. Catzeflis, E. Harley, J. Kirsch, G. Olbricht, J. Wensing and the Noorder Zoo for tissue samples.

Correspondence and requests for materials should be addressed to M.S.S. (e-mail: mark.springer@ucr edu).

\section{Hypothermia in foraging king penguins}

\section{Y. Handrich*, R. M. Bevan $\dagger$, J.-B. Charrassin ${ }^{\star}$, P. J. Butler $\dagger$, K. Pütz $\ddagger$, A. J. Woakes $\dagger$, J. Lage ${ }^{\star} \&$ Y. Le Maho*}

* Centre d'Ecologie et Physiologie Energétiques, Centre National de la Recherche Scientifique, 23 rue Becquerel, 67087 Strasbourg cedex 2, France

$\dagger$ School of Biological Sciences, University of Birmingham, Edgbaston, Birmingham B15 2TT, UK

$\ddagger$ Abteilung Meereszoologie, Institut für Meereskunde, Düsternbrooker Weg 20, D-24105 Kiel, Germany

The ability to dive for long periods increases with body size ${ }^{1}$, but relative to the best human divers, marine birds and mammals of similar or even smaller size are outstanding performers. Most trained human divers can reach a little over $100 \mathrm{~m}$ in a singlebreath dive lasting for $4 \mathrm{~min}$ (ref. 2), but king and emperor penguins (weighing about 12 and $30 \mathrm{~kg}$, respectively) can dive to depths of 304 and $534 \mathrm{~m}$ for as long as 7.5 and $\mathbf{1 5 . 8} \mathrm{min}$, respectively $^{3-5}$. On the basis of their assumed metabolic rates, up to half of the dive durations were believed to exceed the aerobic dive limit, which is the time of submergence before all the oxygen stored in the body has been used $\mathrm{up}^{4,6,7}$. But in penguins and many diving mammals ${ }^{7,8}$, the short surface intervals between dives are not consistent with the recovery times associated with a switch to anaerobic metabolism ${ }^{4}$. We show here that the abdominal temperature of king penguins may fall to as low as $11^{\circ} \mathrm{C}$ during sustained deep diving. As these temperatures may be 10 to $20^{\circ} \mathrm{C}$ below stomach temperature, cold ingested food cannot be the only cause of abdominal cooling. Thus, the slower metabolism of cooler tissues resulting from physiological adjustments associated with diving per se, could at least partly explain why penguins and possibly marine mammals can dive for such long durations.

King penguins are pelagic predators. To obtain food for their chicks, the parents forage at sea up to the subantarctic or polar frontal zones, $300-1,000 \mathrm{~km}$ away from their breeding colony ${ }^{9,10}$. They essentially rely on myctophid fish, of which most are captured in daytime at $150-300 \mathrm{~m}$ depths ${ }^{11}$. As sea temperatures there are $4{ }^{\circ} \mathrm{C}$ or lower, their stomachs are cooled by ingested prey ${ }^{12,13}$. In freely foraging king penguins, which normally have a body temperature of $38^{\circ} \mathrm{C}$ on land, stomach temperatures as low as $19^{\circ} \mathrm{C}$ have been reported ${ }^{11,14}$. There is a $2-4^{\circ} \mathrm{C}$ fall in body temperature during free diving activity in seals ${ }^{15,16}$ and birds ${ }^{17-19}$ and it has been suggested that a slight reduction in body temperature during diving might enhance aerobic diving time $e^{6,15,17,18}$. The cold food that antarctic animals eat could contribute to this hypothermia ${ }^{14,20-22}$, or the aerobic dive limit (ADL) of penguins might be prolonged by a process of temperature-induced metabolic suppression that is independent of stomach cooling.

To investigate these possibilities, the separate influences of feeding and diving on the abdominal temperatures of foraging animals have to be determined. It is important to obtain simultaneous measurements of the temperatures inside and outside the stomach while the animals are freely diving, so that the extent of the temperature changes in relation to diving and feeding activity during the course of a foraging trip can be found. We therefore implanted three data loggers into each of 12 free-ranging king penguins (see Methods). The data loggers (Fig. 1) measured the temperature of each bird at the top $\left(T_{\text {abtop }}\right)$ and bottom $\left(T_{\text {abbot }}\right)$ of the abdomen, as well as inside the stomach $\left(T_{\text {stom }}\right)$. Hydrostatic pressure was also recorded to monitor the diving behaviour. Both the upper-abdominal and stomach loggers measured the full range of temperatures; the lower-abdominal device recorded temperatures 